\title{
Effect of Integrated Nutrient Management Strategies on Nutrient Status and Soil Microbial Population in Aonla (Emblica officinalis Gaertn.) Cv. Na-7
}

\author{
Darpreet Kour $^{1 *}$, V. K. Wali ${ }^{1}$, Parshant Bakshi ${ }^{1}$, Deep Ji Bhat ${ }^{1}$, \\ B. C. Sharma ${ }^{2}$, Vikas Sharma ${ }^{3}$ and B. K. Sinha ${ }^{4}$ \\ ${ }^{1}$ Division of Fruit Science, Sher-e-Kashmir University of Agricultural Sciences and \\ Technology, Chatha, Jammu, 180009 (J\&K), India. \\ ${ }^{2}$ Division of Agronomy, India \\ ${ }^{3}$ Division of Soil Science \& Agri. Chem., India \\ ${ }^{4}$ Division of Plant Physiology, India \\ *Corresponding author
}

\begin{tabular}{|l|}
\hline Ke y w o r d s \\
$\begin{array}{l}\text { Aonla, FYM, } \\
\text { Azotobacter, leaf } \\
\text { and fruit nutrients. }\end{array}$ \\
\hline Article Info \\
\hline $\begin{array}{l}\text { Accepted: } \\
\text { 15 August } 2019 \\
\text { Available Online: } \\
\text { 10 September } 2019\end{array}$
\end{tabular}

\section{Introduction}

Aonla or Indian gooseberry (Emblica officinalis Gaertn.) is indigenous to Indian sub-continent, belongs to the family
Euphorbiaceae. It is the richest source of vitamin C (400-1300 $\mathrm{mg} / 100 \mathrm{~g}$ from pulp) among the fruits next to Barbados cherry (Mandal et al., 2013). Owing to its hardy nature, suitability to various wastelands, high 
productivity, nutritive and therapeutic values, aonla has become an important fruit. Soil type, fertility and nutrient management play an important role in obtaining higher growth and yields of aonla. Indiscriminate use of chemical fertilizers is one of the major causes of decline in soil health with respect to physical, chemical and biological properties. Continuous use of chemical fertilizers without organic manure causes problem to soil health. Modern management practices have led to decline in soil organic matter, increased soil erosion and pollution of surface and ground water (Singh et al., 2012). Due to increase in the cost of chemical fertilizer coupled with limited production, there has been a surge of interest to adopt certain measures such as Integrated Nutrient management (INM) for making its culture eco-friendly by reducing the tradition of inorganic fertilizers, pesticides and other synthetic formulations. Use of inorganic fertilizers along with organic manures and biofertilizers is a proven technology to build up the fertility status of the soil (Bakshi et al., 2017).

Integrated plant nutrient supply system encourages integration of different sources of nutrients organic, inorganic and biological etc. Organic manures like farmyard manure, which is a storehouse of major nutrients apart from containing considerable amount of macro and micronutrients, secondly the use of organic manures increases the organic matter content of the soil by increasing the water holding capacity (Sharma et al., 2013). On the other hand, biofertilizers are preparations containing living cells or latent cells of efficient strains of microorganisms that help crop plants uptake of nutrients by their interactions in the rhizosphere when applied through seed or to soil (Srivastava and Ngullie, 2009). Azotobacter, a free living microbe, acts as plant growth promoting rhizobacteria (PGPR) in the rhizosphere of almost all crops. (Gomare et al., 2013). Azotobacter produces many growth regulators such as IAA and GA which positively influence plant growth (Sharma and Kumar 2008). Therefore, efficient use of integrated plant nutrient system is prerequisite for achieving continuous advances in productivity of fruit crops in ecologically sustainable manner (Chundawat, 2001). It is unfortunate that this minor crop has not been seriously attended by researchers for boosting up its production through judicious application of manures and fertilizers. As such there is no standard practice followed by growers. Thus, a more precise method than generalizing on rates is needed as a guide for nitrogen fertilization practice. Since the leaf is the major tissue in plant functions and a sensitive indicator of nutrient status. Therefore, keeping in view the need for cost effective and ecofriendly aonla production, the present study was undertaken to study the effect of integrated nutrient management strategies on nutrient status and soil microbial populations of aonla cv. NA-7

\section{Materials and Methods}

This study was conducted on 10 year old aonla plants cv. NA-7 having uniform vigour, size and productivity. The experiment was laid out in Farmers Field, Akhnoor, Jammu during 2016 and 2017 in the sub-tropical zone at latitude of $32.89^{\circ}$ North and longitude of $74.74^{\circ}$ East. The experimental soil had $\mathrm{pH}$ 6.92 , sand $64.35 \%$, silt $19.48 \%$, clay $16.17 \%$, organic carbon $0.72 \%$, electrical conductivity $0.70 \mathrm{ds} / \mathrm{m}$, available nitrogen $251.56 \mathrm{~kg} / \mathrm{ha}$, available phosphorus $11.14 \mathrm{~kg} / \mathrm{ha}$, available potassium $137.28 \mathrm{~kg} / \mathrm{ha}$, available calcium $4.84 \mathrm{meq} / 100 \mathrm{~g}$, available magnesium 2.12 meq/100g. Recommended dose of NPK as per Package of practices for horticulture cropsSKUAST-J for aonla was maintained in the experiment, where only nitrogen was manipulated through different sources of fertilization. A total of 12 treatments replicated thrice were evaluated in a 
randomized block design viz., $\mathrm{T}_{1}(100 \% \mathrm{~N}$ as urea), $\mathrm{T}_{2}(25 \% \mathrm{~N}$ as FYM and $75 \% \mathrm{~N}$ as urea), $\mathrm{T}_{3}\left(50 \% \mathrm{~N}\right.$ as FYM and $50 \% \mathrm{~N}$ as urea), $\mathrm{T}_{4}$ $(75 \% \mathrm{~N}$ as FYM and $25 \% \mathrm{~N}$ as urea), $\mathrm{T}_{5}\left(\right.$ Azotobacter $\left.+\mathrm{T}_{1}\right), \mathrm{T}_{6}$ (Azotobacter $\left.+\mathrm{T}_{2}\right), \mathrm{T}_{7}$ $\left(\right.$ Azotobacter $\left.+\mathrm{T}_{3}\right), \mathrm{T}_{8}$ (Azotobacter $\left.+\mathrm{T}_{4}\right), \mathrm{T}_{9}$ (Azotobacter $+100 \% \mathrm{~N}$ as FYM), $\mathrm{T}_{10}(100 \% \mathrm{~N}$ as FYM), $\mathrm{T}_{11}$ (Azotobacter application only) and $\mathrm{T}_{12}$ (Control). Azotobacter culture was applied near active root zone @ 200 g/tree.

Farmyard manure was applied to the trees around the trunk in the first week of February.

Azotobacter with a uniform dose of $200 \mathrm{~g}$ per plant was mixed in jaggery solution prepared separately for each tree and were fed to roots as per the treatment details after 20 days from the application of inorganic fertilizers. The urea was applied in two split doses; viz. first in last week of Februarys and another in August.

Leaf samples from the experimental trees consisting of fully matured leaves from mid position of shoot were collected at full bloom stage (Nayak et al., 2011), thoroughly washed and ground to have a homogenous sample as per method described by Chapman (1964). Nitrogen was estimated by Micro-Kjeldahl's method as suggested by Jackson (1973). Phosphorus was determined by Vanadomolybdophosphoric acid yellow colour method (Jackson, 1973).

Potassium was estimated using flame photometer and calcium, magesium was measured using atomic absorption spectrophotometer. Composite soil sample from the aonla rhizosphere of each treatment was used for estimation of soil microbial population following serial dilution method using specific media for each microbe (Black et al.,1965). The data generated during the course of study was subjected to statistical analysis as prescribed by Panse and Sukhatme (2000).

\section{Results and Discussion}

\section{Leaf nutrient content}

The effect of various treatments on leaf nutrients has been enumerated in Table 1. It was observed from the pooled estimate that various integrated treatment combinations had a significant effect on available leaf nitrogen content where highest leaf nitrogen $(2.78 \%)$ was recorded with the trees receiving 25 per cent nitrogen as FYM +75 per cent nitrogen as urea augmented with Azotobacter $\left(\mathrm{T}_{6}\right)$ followed by plants receiving cent per cent nitrogen through urea + Azotobacter $\left(\mathrm{T}_{5}\right)$ and minimum was recorded under control $\left(\mathrm{T}_{12}\right)$. This increase in uptake of leaf nitrogen was due to integrated application of nutrients through farmyard manures, Azotobacter and urea which added supply of nutrients and well developed root system under balanced nutrient application resulting in better adsorption of water and nutrients (Sharma et al., 2011).

From the perusal of pooled data presented in Table 1 also revealed that leaf phosphorous reached to a highest level of $0.22 \%$ recorded from trees treated with 25 per cent nitrogen as FYM + 75 per cent nitrogen as urea augmented with Azotobacter $\left(\mathrm{T}_{6}\right)$ followed by 0.21 per cent recorded in trees treated with cent per cent nitrogen as urea augmented with Azotobacter $\left(\mathrm{T}_{5}\right)$ and 50 per cent nitrogen through FYM along with 50 per cent nitrogen through urea augmented with Azotobacter $\left(\mathrm{T}_{7}\right)$. Lowest leaf phosphorus content of 0.11 per cent was recorded under control. The increase in phosphorus uptake might have been due to the better availability and translocation of phosphorus under Azotobacter application. Similar increase in phosphorous uptake with the increase in application of nitrogen has been reported by Bala et al., (2011) in aonla. Pooled data in the Table 1 also enumerates the highest leaf potassium (2.44) was recorded under treatment where 
aonla trees were treated with 50 per cent nitrogen as FYM and 50 per cent nitrogen as urea augmented with Azotobacter $\left(\mathrm{T}_{7}\right)$ followed by 2.43 per cent where the trees were treated with 75 per cent nitrogen as FYM and 25 per cent nitrogen as urea augmented with Azotobacter $\left(\mathrm{T}_{8}\right)$. Lowest leaf potassium (2.19 per cent) was recorded under control $\left(\mathrm{T}_{12}\right)$. This increase in leaf potassium of aonla may be due to combined use of organic and inorganic sources of fertilizers on potassium content and uptake by the fruits that may be ascribed to its role in improving soil physical properties, inturn there is better root resulting more uptake of potassium from native sources (Sharma et al., 2013).

The pooled data in Table 1 also showed that maximum leaf calcium $(2.33 \%)$ was recorded in leaves collected from trees receiving 25 per cent nitrogen as FYM +75 per cent nitrogen as urea augmented with Azotobacter $\left(\mathrm{T}_{6}\right)$ followed by treatment comprising of cent per cent application of nitrogen as urea augmented with Azotobacter $\left(\mathrm{T}_{5}\right)$ and cent per cent application of nitrogen as urea $\left(\mathrm{T}_{1}\right)$ where 2.30 per cent calcium content, respectively, was obtained.).

Lowest leaf calcium content of 1.84 per cent was recorded under control. This increase in nutrients was, may be, due to production of enzyme complexes by nitrogenfixers and which solubilized the unavailable form of nutrient elements and made them available (Narayan et al., 2004).

The statistical analysis of the pooled data presented in Table 4 indicate that leaf magnesium reached to highest level of 0.47 per cent was recorded from trees treated with cent per cent application of nitrogen as urea augmented with Azotobacter $\left(\mathrm{T}_{5}\right), 25$ per cent application of nitrogen as FYM and 75 per cent nitrogen as urea augmented with
Azotobacter $\left(\mathrm{T}_{6}\right), 50$ per cent application of nitrogen as FYM and 50 per cent nitrogen as urea augmented with Azotobacter $\left(\mathrm{T}_{7}\right)$ and cent per cent nitrogen as FYM augmented with Azotobacter $\left(\mathrm{T}_{9}\right)$ as compared (0.28 per cent) to control $\left(\mathrm{T}_{12}\right)$.

It was also observed that Azotobacter influenced the increase in length of main root and the number of secondary roots, which enhanced the uptake of mineral elements.

The results are in line with Singh et al., (2004) where they observed that Azotobacter influenced the increase of length of main root and the number of secondary roots, which enhanced uptake of the mineral element uptake. The better foliar nutrient of aonla leaves as observed in present investigation has also been partially supported by Marathe et al., (2012) in sweet orange and Goswami et al., (2012) in guava.

\section{Fruit nutrient content}

Data regarding effect of different integrated nutrient management treatments on fruit nutrient content is presented in Table 2. An inquisition of pooled data revealed that highest fruit nitrogen content of 0.14 per cent was recorded with the trees receiving 25 per cent nitrogen as FYM +75 per cent nitrogen as urea + Azotobacter $\left(\mathrm{T}_{6}\right)$ followed by cent per cent nitrogen as urea $\left(T_{1}\right)$, cent per cent nitrogen as urea in combination with Azotobacte $\left(\mathrm{T}_{\mathrm{s}}\right), 50$ per cent nitrogen as FYM +75 per cent nitrogen as urea + Azotobacter $\left(\mathrm{T}_{7}\right)$ and where $0.13 \%$ fruit nitrogen was recorded. Minimum leaf nitrogen content was recorded under control $\left(\mathrm{T}_{12}\right)$.

Fruit phosphorus reached to a highest level of $0.030 \%$ was recorded with the trees receiving 25 per cent nitrogen as FYM +75 per cent nitrogen as urea augmented with Azotobacter $\left(\mathrm{T}_{6}\right)$. 
Table.1 Leaf macronutrient composition of aonla cv- NA-7 as affected by different INM treatments (Pooled mean of two years)

\begin{tabular}{|c|c|c|c|c|c|}
\hline Treatments & $\begin{array}{c}\text { Nitrogen } \\
(\%)\end{array}$ & $\begin{array}{c}\text { Phosphorous } \\
(\%)\end{array}$ & $\begin{array}{c}\text { Potassium } \\
(\%)\end{array}$ & $\begin{array}{c}\text { Calcium } \\
(\%)\end{array}$ & $\begin{array}{c}\text { Magnesium } \\
(\%)\end{array}$ \\
\hline$T_{1}(100 \%$ of $N /$ tree through Urea) & 2.67 & 0.17 & 2.31 & 2.30 & 0.37 \\
\hline $\mathrm{T}_{2}(75 \% \mathrm{~N}$ through Urea+ $25 \%$ through FYM) & 2.67 & 0.18 & 2.36 & 2.27 & 0.39 \\
\hline $\mathrm{T}_{3}(50 \% \mathrm{~N}$ through Urea $+50 \%$ through $\mathrm{FYM})$ & 2.62 & 0.17 & 2.39 & 2.19 & 0.41 \\
\hline $\mathrm{T}_{4}(25 \% \mathrm{~N}$ through Urea $+75 \%$ through $\mathrm{FYM})$ & 2.53 & 0.18 & 2.43 & 2.05 & 0.39 \\
\hline $\mathbf{T}_{5}\left(\right.$ Azotobacter $\left.+\mathbf{T}_{1}\right)$ & 2.75 & 0.21 & 2.35 & 2.30 & 0.47 \\
\hline $\mathbf{T}_{6}\left(\right.$ Azotobacter $\left.+\mathbf{T}_{2}\right)$ & 2.78 & 0.22 & 2.42 & 2.33 & 0.47 \\
\hline $\mathbf{T}_{7}\left(\right.$ Azotobacter $\left.+\mathbf{T}_{3}\right)$ & 2.72 & 0.21 & 2.44 & 2.21 & 0.47 \\
\hline $\mathbf{T}_{8}\left(\right.$ Azotobacter $\left.+\mathbf{T}_{4}\right)$ & 2.58 & 0.18 & 2.43 & 2.24 & 0.45 \\
\hline $\mathrm{T}_{9}($ Azotobacter $+100 \% \mathrm{~N}$ through $\mathrm{FYM})$ & 2.56 & 0.17 & 2.42 & 2.02 & 0.47 \\
\hline $\mathrm{T}_{10}(100 \% \mathrm{~N}$ through FYM $)$ & 2.44 & 0.14 & 2.33 & 1.93 & 0.37 \\
\hline $\mathbf{T}_{11}$ (Azotobacter @ 200g/tree) & 2.41 & 0.12 & 2.33 & 1.89 & 0.35 \\
\hline $\mathbf{T}_{12}$ (Control) & 2.29 & 0.11 & 2.19 & 1.84 & 0.28 \\
\hline CD $(5 \%)$ & 0.035 & 0.008 & 0.010 & 0.031 & 0.016 \\
\hline
\end{tabular}


Table.2 Fruit macronutrient composition of aonla cv- NA-7 as affected by different INM treatments (Pooled mean of two years)

\begin{tabular}{|c|c|c|c|c|c|}
\hline Treatments & $\begin{array}{l}\text { Nitrogen } \\
(\%)\end{array}$ & $\begin{array}{c}\text { Phosphorous } \\
(\%)\end{array}$ & $\begin{array}{c}\text { Potassium } \\
(\%)\end{array}$ & $\begin{array}{c}\text { Calcium } \\
(\%)\end{array}$ & $\begin{array}{c}\text { Magnesium } \\
(\%)\end{array}$ \\
\hline$T_{1}(100 \%$ of $N /$ tree through Urea $)$ & 0.13 & 0.025 & 0.22 & 0.029 & 0.016 \\
\hline $\mathrm{T}_{2}(75 \% \mathrm{~N}$ through Urea+ $25 \%$ through FYM) & 0.12 & 0.027 & 0.23 & 0.029 & 0.016 \\
\hline $\mathrm{T}_{3}(50 \% \mathrm{~N}$ through Urea $+50 \%$ through $\mathrm{FYM})$ & 0.12 & 0.027 & 0.24 & 0.030 & 0.016 \\
\hline $\mathrm{T}_{4}(25 \% \mathrm{~N}$ through Urea $+75 \%$ through FYM $)$ & 0.11 & 0.025 & 0.24 & 0.030 & 0.016 \\
\hline $\mathbf{T}_{5}\left(\right.$ Azotobacter $\left.+\mathbf{T}_{1}\right)$ & 0.13 & 0.029 & 0.26 & 0.031 & 0.020 \\
\hline $\mathbf{T}_{6}\left(\right.$ Azotobacter $\left.+\mathbf{T}_{2}\right)$ & 0.14 & 0.030 & 0.27 & 0.031 & 0.020 \\
\hline $\mathbf{T}_{7}\left(\right.$ Azotobacter $\left.+\mathbf{T}_{3}\right)$ & 0.13 & 0.029 & 0.30 & 0.030 & 0.019 \\
\hline $\mathbf{T}_{8}\left(\right.$ Azotobacter $\left.+\mathbf{T}_{4}\right)$ & 0.12 & 0.028 & 0.29 & 0.028 & 0.016 \\
\hline $\mathrm{T}_{9}($ Azotobacter $+100 \% \mathrm{~N}$ through FYM) & 0.12 & 0.027 & 0.28 & 0.031 & 0.019 \\
\hline $\mathbf{T}_{10}(100 \% \mathrm{~N}$ through FYM) & 0.11 & 0.022 & 0.25 & 0.028 & 0.016 \\
\hline $\mathrm{T}_{11}$ (Azotobacter@ 200g/tree) & 0.11 & 0.021 & 0.21 & 0.027 & 0.016 \\
\hline $\mathbf{T}_{12}($ Control $)$ & 0.10 & 0.017 & 0.19 & 0.023 & 0.011 \\
\hline CD $(5 \%)$ & 0.011 & 0.001 & 0.010 & 0.001 & 0.001 \\
\hline
\end{tabular}


Table.3 Soil microbial population of aonla rhizpsphere as affected by different INM treatments (Pooled mean of two years)

\begin{tabular}{|c|c|c|c|}
\hline Treatments & $\begin{array}{l}\text { Azotobacter counts } \\
\left(\times 10^{4} \mathrm{cfu}\right)\end{array}$ & $\begin{array}{l}\text { Bacterial counts }(x \\
\left.10^{6} \mathrm{cfu}\right)\end{array}$ & $\begin{array}{l}\text { Fungal counts } \\
\quad\left(x 1^{5} \mathrm{cfu}\right)\end{array}$ \\
\hline$T_{1}(100 \%$ of $N /$ tree through Urea $)$ & 9.7 & 11.0 & 9.7 \\
\hline $\mathrm{T}_{2}(75 \% \mathrm{~N}$ through Urea+ $25 \%$ through FYM) & 10.4 & 11.8 & 11.0 \\
\hline $\mathrm{T}_{3}(50 \% \mathrm{~N}$ through Urea $+50 \%$ through $\mathrm{FYM})$ & 11.6 & 12.4 & 11.8 \\
\hline $\mathrm{T}_{4}(25 \% \mathrm{~N}$ through Urea $+75 \%$ through FYM $)$ & 14.3 & 12.9 & 13.8 \\
\hline $\mathbf{T}_{5}\left(\right.$ Azotobacter $\left.+\mathbf{T}_{1}\right)$ & 19.4 & 15.2 & 18.8 \\
\hline $\mathbf{T}_{6}\left(\right.$ Azotobacter $\left.+\mathbf{T}_{2}\right)$ & 23.7 & 24.8 & 21.1 \\
\hline $\mathbf{T}_{7}\left(\right.$ Azotobacter $\left.+\mathbf{T}_{3}\right)$ & 26.0 & 27.1 & 23.5 \\
\hline $\mathbf{T}_{8}\left(\right.$ Azotobacter $\left.+\mathbf{T}_{4}\right)$ & 26.3 & 28.1 & 24.0 \\
\hline $\mathrm{T}_{9}($ Azotobacter $+100 \% \mathrm{~N}$ through FYM $)$ & 27.3 & 28.5 & 24.9 \\
\hline $\mathrm{T}_{10}(100 \% \mathrm{~N}$ through $\mathrm{FYM})$ & 14.2 & 13.3 & 14.4 \\
\hline $\mathbf{T}_{11}$ (Azotobacter@200g/tree) & 22.4 & 20.5 & 20.8 \\
\hline $\mathbf{T}_{12}$ (Control) & 4.7 & 5.8 & 2.9 \\
\hline CD $(5 \%)$ & 0.99 & 1.10 & 0.92 \\
\hline
\end{tabular}


The fruit potassium attained highest level of 0.30 per cent was observed in plants receiving 50 per cent nitrogen as FYM $+75 \%$ nitrogen as urea + Azotobacter $\left(\mathrm{T}_{7}\right)$ followed by trees treated with 75 per cent nitrogen as FYM and 25 per cent nitrogen as urea augmented with Azotobacter $\left(\mathrm{T}_{8}\right)$ and trees receiving cent per cent nitrogen as FYM augmented with Azotobacter $\left(\mathrm{T}_{9}\right)$ with the corresponding values of 0.30 per cent and 0.29 per cent, respectively while it was found minimum $(0.19$ per cent $)$ in control $\left(\mathrm{T}_{12}\right)$. The pooled data also showed that highest calcium in fruits ( 0.031 per cent) was recorded in fruits treated with cent per cent nitrogen as urea in combination with Azotobacte $\left(\mathrm{T}_{5}\right)$ and trees treated with 25 per cent nitrogen as FYM +75 per cent nitrogen as urea augmented with Azotobacter $\left(\mathrm{T}_{6}\right)$. Magnesium content in fruits did not show much significant difference among different treatments and ranged from 0.011 to $0.020 \%$, lowest being observed in control $\left(\mathrm{T}_{12}\right)$. This increase in fruit nutrient may be due to well known fact that the leaves are the major site of photosynthesis and act as major 'source' for the 'sink'. It was observed that Azotobacter helped increase length of the main root and the number of secondary roots in guava, which enhanced uptake of the mineral element as a result of better translocation to leaves for growth and development of the fruit. The above results are in line with the studies of Bakshi et al., (2017) in Kinnow and Rana (2001) who found increase in nitrogen, potassium and calcium content of strawberry due to nitrogen and Azotobacter application and also reported no effect of various nitrogen fixers and urea on magnesium content of the berries.

\section{Soil microbial population}

The pooled data on amount of soil microbial population are presented in Table 3 showed that after fruit harvest maximum Azotobacter population $\left(27.3 \times 10^{4} \mathrm{cfu}\right.$ per gram soil $)$, bacterial population $\left(28.5 \times 10^{6} \mathrm{cfu}\right.$ per gram soil) and fungal population $\left(24.9 \times 10_{5} \mathrm{cfu} / \mathrm{g}\right.$ soil) was observed in $\mathrm{T}$, with the application of full dose of FYM augmented with Azotobacter, the minimum was observed in control $\left(\mathrm{T}_{12}\right)$. The increased in Azotobacter population might be due to the fact that organic matter serves as energy source for growth and multiplication of Azotobacter. Awasthi et al., (1996) observed increase in spore number with increased application of $\mathrm{N}$ and $\mathrm{P}$ through organic sources. It was also observed that increased nitrogen application through organic source reduced microbial population. The present results are in conformity with the findings of Kuttimani et al., (2017) who reported that application of organic manures enhanced the microbial biomass (fungi and bacteria) than inorganic fertilizers because they increase the proportion of liable carbon and nitrogen directly by stimulating the activity of microorganism.

On the basis of the aforesaid findings, it is evident that integrated nutrient management system standardized the schedule of manure and fertilizer application in aonla for sustaining the soil fertility to enhance the production potential and reduce the requirement of inorganic fertilizers. The findings have clearly indicated that there was a positive effect of fertilizers when nitrogen was manipulated through different sources, viz. FYM, biofertilizers and inorganic fertilizers. The results also indicated that there was substantial improvement in leaf and fruit nutrient status of aonla through use of integrated nutrient management system comprising inorganic fertilizers, FYM and Azotobacter. Also integration of organic manure along with Azotobacter increased soil health in terms of microbial populations. Based on the experimental results obtained, it may be finally concluded that application of 25 per cent nitrogen per tree through FYM and 75 per cent nitrogen per tree through urea 
along with Azotobacter @ 200 g/tree for increasing leaf and fruit nutrient status of aonla cv- NA-7.

\section{References}

Awasthi, R.P., Godhra, R.K. and Kaith, N.S. 1996. Interaction effect of VAM and Azotobacter inoculation on peach seedling. Indian Journal of Horticulture, 53: 8-13.

Bakshi, M., Wali, V.K., Bakshi, P., Sharma, A., Sharma, D. and Shah, R.A. 2017. Integrated nutrient management induced changes in nutrient uptake, fruit yield and quality of Kinnow mandarin. Indian Journal of Agricultural Sciences, 87(3): 414-418.

Bala, S. Chaudhary, V.R. and Shukla, H.S. 2011. Effect of organic manure and biofertilizers with graded dose of NPK on soil and leaf nutrient status of aonla (Emblica officinalis Gaertn.) cv. Banarasi. Karnataka Journal of Agricultural Sciences, 24(5): 709-711.

Black C A, Evans D D, Whit J L, Ensminger L E and Clark F E. 1965. Methods of Soil Analysis, Part (I \& II). Agronomy 9, American Society of Agronomy, Madison, Washington, USA.

Chapman, H.D. 1964. Suggested foliar sampling and handling techniques for determining nutrient status of some field, horticultural and plantation crops. Indian Journal of Horticulture. 21: 98-118.

Chundawat, B.S. 2001. Integrated nutrient management in tropical and subtropical fruits. Proc. National Seminar on New Horizon in production and post management of tropical and subtropical fruits. pp. Res. 21(4): 499-503.

Gomare K S, Mese M and Shetkar Y. 2013. Isolation of Azotobacter and cost effective production of biofertilizer.
Biotechnology 3(5): 54-6.

Goswami, A. K., Lal, S., Thakare, M., Pratibha, Mishra, D. S. and Kumar, R. 2015. Studies on integrated nutrient management on yield and quality of guava cv. Pant Prabhat. Indian Journal of Horiticulture, 72(1): 139-142.

Jackson, M. L. 1973. Soil Chemical Analysis. Prentice Hall of India Pvt. Ltd. New Delhi. 498pp.

Kuttimani, R., Somasundaram, E. and Velayudham, K. 2017. Effect of Integrated Nutrient Management on Soil Microorganisms under Irrigated Banana. International Journal of Current Microbiology and Applied Sciences, 6(11): 2342-2350.

Mandal, K. K., Rajak, A., Debnath, S. and Hasan, M. A. 2013. Integrated nutrient management in aonla cv. A-7 in the red lateritic region of West Bengal. Journal of Crop and Weed. 9(1): 121123.

Marathe, R.A., Bharambe, P. R., Sharma, R. and Sharma, U. C. 2012. Leaf nutrient composition, its correlation with yield and quality of sweet orange and soil microbial population as influenced by INM in vertisol of Central India. Indian Journal of Horticulture, 69(3): 317-321.

Narayan, R., Magray, G.H, Ahmed, N. and Samanta, A. 2004. Effect of organic manures on nutrient uptake and quality of capsicum (Capsicum annum var. Grossum L.) The Horticulture Journal, 17:141-144.

Nayak, A.K., Sharma, D,K., Mishra, V.K., Singh, G. and Swarup, A. 2011. Diagnosis and recommendation integrated system approach for nitrogen, phosphorus, potassium, and zinc foliar diagnostic norms for aonla in central indo-gangetic plains. Journal of Plant Nutrition, 34:547-556 
Panse, V.G. and Sukhatme, P.V. 2000. Statistical methods for agricultural workers. Publications and Information, Division of ICAR, New Delhi.

Rana, R.K. 2001. Studies on the influence of nitrogen fixers and plant bioregulators on growth, yield and quality of strawberry cv. Chandler. Ph.D. thesis, Dr. Y.S. Parmar University of Horticulture and Forestry, Solan.

Sharma S D and Kumar P. 2008. Relationship of arbuscularmycorrhizal fungi and Azotobacter with plant growth, fruit yield, soil and leaf nutrient status of mango orchards in North-Western Himalayan region of India. Journal of Applied Horticulture 10(2): 172-8.

Sharma, A., Wali, V. K., Bakshi, P. and Jasrotia, A. 2013. Effect of organic and inorganic fertilizers on quality and shelf life of guava (Psidium guajava L.) cv. Sardar. The Bioscan, 8(4): 1247-1250.
Sharma, A., Wali, V.K., Bakshi, P. and Jamwal, M. 2011. Effect of organic manures and biofertilizers on leaf and fruit nutrient status in guava (Psidium guajava L.) cv. Sardar. Journal of Horticulture Science, 6(2): 169-171.

Singh, A. K., Singh, Sanjay. and Rao, V. V. A. 2012. Influence of organic and inorganic nutrient sources on soil properties and quality of aonla in hot semi-arid ecosystem. Indian Journal of Horticulture, 69 (1): 50-54.

Singh, T.R., Singh, S., Singh S.K., Singh, M.P. and Srivastava, B.K. 2004. Effect of integrated nutrient management on crop nutrient uptake and yield under okra-pea-tomato cropping system in Molisol. Indian Journal of Horticulture, 61: 312-14.

Srivastava A K and Ngullie E. 2009a. Integrated nutrient management: Theory and practice. Dynamic Soil, Dynamic Plant 3(1): 1-30.

\section{How to cite this article:}

Darpreet Kour, V. K. Wali, Parshant Bakshi, Deep Ji Bhat, B. Ces. Sharma, Vikas Sharma and Sinha, B. K. 2019. Effect of Integrated Nutrient Management Strategies on Nutrient Status and Soil Microbial Population in Aonla (Emblica Officinalis Gaertn.) Cv. Na-7. Int.J.Curr.Microbiol.App.Sci. 8(09): 1272-1281. doi: https://doi.org/10.20546/ijcmas.2019.809.146 